\title{
An Analysis of the Critical Thinking Standards and Democratical Attitudes of Prospective Elementary School Teachers In Terms Of Certain Variables
}

\author{
Birsel AYBEK ${ }^{1}$, Serkan ASLAN ${ }^{2 *}$
}

${ }^{1 .}$ Cukurova Üniversity, Faculty of Education, Adana, Türkiye

${ }^{2}$ Ministry of National Education, Nuri Ozaltın Elemantary School, Elazığ, Türkiye

\begin{tabular}{l} 
ARTICLE INFO \\
\hline Article History: \\
Received \\
31.07 .2017 \\
Received in revised \\
form 29.11.2017 \\
Accepted \\
06.12.2017 \\
Available online \\
28.12.2017
\end{tabular}

\begin{abstract}
The objective of this study is to analyze the critical thinking standards and democratical attitudes of prospective elementary school teachers in terms of certain variables. Descriptive survey model was used in this research. 321 prospective elementary school teachers participated in the study. Personal Information Form, "Democracy Oriented Attitude Scale" and "Critical Thinking Standards Scale" were used as data collection tools. Descriptive statistics and multivariate variance analyses methods were used (MANOVA) for the analysis of the data. Following the research, it was observed that the opinions of prospective elementary school teachers concerning the critical thinking standards and Democracy oriented attitude scales were as "I agree". No significant difference was observed between the critical thinking standards scores and democracy oriented attitude scores of the prospective elementary school teachers in terms of gender, university entrance score type variables, however, significant difference was observed in terms of their class levels and graduated high school types. Recommendations have been developed depending upon the research findings.
\end{abstract}

(c) 2017 AUJES. All rights reserved Keywords: Democracy, critical thinking standards, attitude

\section{Extended Abstract}

\section{Purpose}

The purpose of this study is to examine the critical thinking standards of candidate classroom teachers as well as their attitude towards democracy from the perspective of certain variables.

\footnotetext{
"Corresponding author's address: Ministry of National Education, Nuri Ozaltın Elemantary School, Elazığ, Turkey e-mail: aslan.s1985@gmail.com
} 


\section{Method}

In the research, as one of the survey models, the descriptive survey model was used. The descriptive surveys are researches made on large groups, where the opinions, attitudes concerning one fact and incident are taken, aiming to describe facts and incidents (Karakaya, 2012: 59). This research method is used for the purpose of defining the structure of objects, communities, institutions and the functioning of events (Cohen, Manion \& Morrison, 2007). In this research too, the descriptive survey model was used to examine as is from the perspective of certain variables the critical thinking standards and attitudes towards democracy. The population of the research consists of candidate teachers studying in the Department of Classroom Teaching in Çukurova University. 326 candidate students from the $1^{\text {st }}, 2^{\text {nd }}, 3^{\text {rd }}$ and $4^{\text {th }}$ classes have participated to the research. As most of the population could be accessed, samples were not selected. In the research; the "Attitude towards Democracy" developed by Oral (2008) and "Critical Thinking Standards" developed by Aybek, Aslan, Dinçer and CoşkunArısoy (2015) were used as data collecting tool. Descriptive statistics and multivariate analysis of variance (MANOVA) were used in the analysis of data.

\section{Results}

As a result of the research, candidate teachers were observed to indicate their opinion as agree in the level of critical thinking standards and attitude scale towards democracy. While no significant difference was found regarding variables of gender and university entrance score types of the candidate teachers, a significant difference was found regarding class levels and graduated high school types.

\section{Discussion and Conclusion}

As a result of the research, candidate teachers were observed to indicate their opinion as agree in the level of critical thinking standards and attitude scale towards democracy. Based on this result, it can be said that the teachers have a high standard of critical thinking and that their attitudes towards democracy are positive and at a high level. Researchers evaluate as positive the high levels of critical thinking and attitudes towards democracy. High critical thinking standards of candidate teachers shall facilitate instilling these standards in the students. Similarly, the high levels of democratic attitude in candidate teachers makes think that they will be democratic in learning-teaching environment and that they will instill the value of democracy in students. In the researches made by Evin-Gencel and Güzel-Candan (2014), Kuvaç and Koç (2014) and Kartal (2012) the level of critical thinking tendencies of teachers were found as high and medium; in the researches made by Alkın-Şahin, Tunca, Ulubey (2014) as well as Can and Kaymakçı (2015) the level of critical thinking tendencies of candidate teachers was found low. In the research made by Özdaş, Ekinci and Bindak (2014) too, the 
teachers' attitude towards democracy was found to be at a high level. These results are supporting the result of the research.

The candidate teachers' critical thinking standards and their attitudes towards democracy did not display a significant difference regarding gender. As there was no significant difference regarding gender in the critical thinking standards and attitudes towards democracy of candidate teachers, this may be interpreted as the gender being without effect on critical thinking standards and attitudes towards democracy. The critical thinking standards and attitudes towards democracy of candidate teachers were found to be without any significant difference regarding university entrance score types. It can be said that there is similarity between critical thinking standards and attitudes towards democracy and their university entrance score types of candidate teachers regarding their university entrance score types.

The result obtained implies that a significant difference exists between the critical thinking standards of candidate teachers and their attitudes towards democracy in terms of the variable of class level. This brings out that the critical thinking standards and attitudes towards democracy of candidate teachers vary according to the class level. When averages are studied, the critical thinking standards and democratic attitudes of students of the final class were found to be higher. This is an expected situation. As a consequence of all the education and courses taken by candidate teachers during their university life, high levels of critical thinking standards and democratic attitudes in final year students is an expected situation. This result is supportive of this expected situation. Furthermore, the fact that instructors have acted democratically in the teaching-learning environment and have provided information on the critical thinking skills may have contributed in coming to such a conclusion. In the researches made by Shin, Lee, Ha and Kin (2006) a significant difference was found in the critical thinking tendencies of candidate teachers according to their class level variables. In the research made by Genç and Kalafat (2008) a significant difference was not found between the democratic attitudes of candidate teachers and the level of the class they are studying. A significant difference was found to occur according to the high school types candidate teachers have graduated in their critical thinking standards and attitudes towards democracy. Based on this result, it can be said that the type of high schools candidate teachers have graduated from has an effect on their critical thinking standards and attitudes towards democracy. When averages are studied, candidate teachers who are general high school graduates were found to have high standards of critical thinking standards and attitudes towards democracy. Based on this result, it is possible to say that an effort is made to develop critical thinking skills and democratic attitudes in general high schools. 


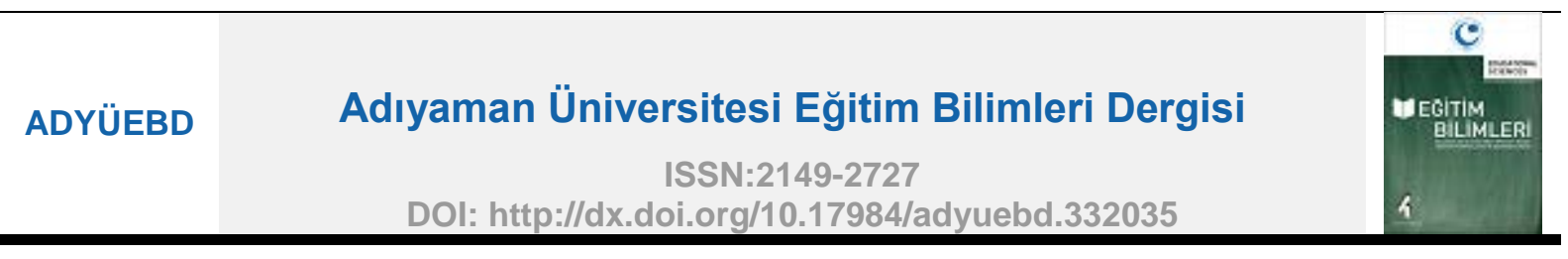

Sınıf Öğretmeni Adaylarının Eleştirel Düşünme Standartları ile Demokrasiye Yönelik Tutumlarının Bazı Değişkenler Açısından İncelenmesi

\author{
Birsel AYBEK ${ }^{1}$, Serkan ASLAN ${ }^{2 *}$
}

1. Çukurova Üniversitesi, Eğitim Fakültesi, Adana, Türkiye

2. Milli Eğitim Bakanlığı, Nuri Özaltın Ilkokulu, Elazığ, Türkiye

\begin{tabular}{l} 
MAKALE BİLGI \\
\hline Makale Tarihçesi: \\
Alındı 31.07.2017 \\
Düzeltilmiş hali \\
alındı 29.11.2017 \\
Kabul edildi \\
06.12 .2017 \\
Çevrimiçi \\
yayınlandı \\
28.12.2017
\end{tabular}

\begin{abstract}
ÖZET
Bu çalışmanın temel amacı, sınıf öğretmeni adaylarının eleştirel düşünme standartları ile demokrasiye yönelik tutumlarını bazı değişkenler açısından incelemektir. Araştırmada tarama modellerinden betimsel tarama modeli kullanılmıştır. Araştırmanın evrenini Çukurova Üniversitesi'nde eğitim fakültesinde öğrenim gören $1,2,3$ ve 4 . sınıf öğretmeni adayları oluşturmaktadır. Araştırmada evrenin çoğuna ulaşıldığından ayrıca örneklem seçimine gidilmemiştir. Araştırmaya 326 öğretmen adayı katılmıştır. Araştırmada veri toplama aracı olarak; Oral (2008) tarafından geliştirilen "Demokrasiye Yönelik Tutum" ölçeği ile Aybek, Aslan, Dinçer ve Coşkun-Arısoy (2015) tarafından geliştirilmiş olan "Eleştirel Düşünme Standartları" ölçeği kullanıımıştır. Verilerin analizinde betimsel istatistik ve çok değişkenli varyans analizi (MANOVA) kullanılıışır. Araştırma sonucunda öğretmen adayları, eleştirel düşünme standartları ile demokrasiye yönelik tutum ölçeklerine katılıyorum düzeyinde görüş belirttikleri görülmüştür. Öğretmen adaylarının; eleştirel düşünme standartları puanları ile demokrasiye yönelik tutum puanları cinsiyet ve üniversiteye giriş puan türü değişkenleri açısından anlamlı farklıık bulunmazken, sınıf düzeyleri ve mezun olunan lise türleri açısından anlamlı farkııık bulunmuştur. Araştırma bulgularına dayalı olarak öneriler geliştirilmiştir.
\end{abstract}

(c) 2017 AUJES. Tüm hakları saklıdır Anahtar Kelimeler: Demokrasi, eleştirel düşünme standartları, tutum

\title{
Giriş
}

Yirmi birinci yüzyılda bilimde, teknolojide, sanatta, edebiyatta kısaca hayatın her alanında büyük değişmeler ve ilerlemeler meydana gelmiştir. Bu değişmeler ve ilerlemeler eğitimi de etkilemiştir. Günümüzde eğitimin amacı, çağın gerektirdiği değişimlere ayak uydurabilen, üst düzey düşünme becerilerine sahip, demokratik ve evrensel değerleri benimsemiş bireyler yetiştirmektir. Günümüzde üst düzey düşünme becerilerinden bir olan eleştirel düşünme becerisinin bireylere kazandırılması ve demokratik değerlere sahip bireylerin yetiştirilmesi için gelişmiş ve gelişmekte olan ülkeler öğretim programlarında değişiklikler yapmaktadır. Türkiye'de de 2005 yılından itibaren ilkokul öğretim programlarında değişikliğe gidilmiş, üst düzey düşünme

\footnotetext{
*Sorumlu yazarın adresi: Milli Eğitim Bakanlığı, Nuri Özaltın İlkokulu, Elazığ e-posta: aslan.s1985@gmail.com
} 
becerilerine ve demokratik değerlere öğretim programlarında yer verilmiştir (Milli Eğitim Bakanlığı [MEB], 2017a; 2017b; 2017c).

Eleştirel düşünme ile ilgili farklı araştırmacılar tarafından farklı tanımlar yapılmıştır. Paul ve Elder (2007) eleştirel düşünmeyi, düşünmeyi geliştirmek amacıyla onu analiz etme ve değerlendirme sanatı olarak tanımlarken Halpern (2003) eleştirel düşünmeyi "istenilen davranışların olabilirliğini arttıran bilişsel beceri ya da stratejilerin kullanılması" olarak tanımlamaktadır. Drennan (2010) eleştirel düşünmenin, problem çözme, karar verme, çıkarımda bulunma, farklı düşünme ve mantık kavramlarından oluştuğunu belirtmiştir. Yukarıdaki tanımlamalardan da anlaşılacağı üzere eleştirel düşünme, yaşamın tüm yönlerini etkili biçimde kullanılmasına olanak sağlayan bir düşünme biçimidir (Kökdemir, 2003). Eleştirel düşünme becerisinin kazandırılmasında bazı standartların gerekli olduğu düşünülmektedir.

Nosich (2011) düşünmenin yüksek standartları karşılaması gerektiğini savunmuş, bu nedenle üst düzey düşünme becerileri içerisinde yer alan eleştirel düşünme ile ilgili standartlar ortaya koymuştur. Nosich (2011), standartlar sayesinde kişi eleştirel olmayan düşünceleri dışarı da bırakmaktadır, yani eleştirel düşünme standartları filtre görevi görmektedir. Ayrıca Nosich'e (2011) göre, eleştirel düşünme standartları, mantıklı düşünmenin önkoşuludur. Bu nedenle, bir düşüncenin mantıklı olup olmadığını belirleyebilmek için bu düşüncenin eleştirel düşünme standartlarından geçmesi gerekmektedir. Noisch'e (2011) göre bu standartlar açıklık, doğruluk, önem/alaka, yeterlilik, derinlik/genişlik ve kesinlikten oluşmaktadır. İlk olarak açıklık standardında, düşüncenin açık bir şekilde ifade edilmesi, kolaylıkla anlaşılması, yanlış anlaşı ıma ihtimali taşımaması, gerektiğinde ayrıntıya girilerek açıklanması, örneklerle somut hale getirilmesi, görsellerle desteklenmesi, sade ve anlaşılır olması gerekmektedir.

Doğruluk standardında; düşüncenin doğru olması, mantıklı olması, verilen bilgilerin güvenilir olması, bilginin doğru bir sıra halinde verilmesi, bilgilerin güvenilir kaynaklara dayanması, gerçeği ifade etmesi gerekmektedir. Önem/alaka standardında, düşüncelerin aktarılırken önemli noktaların vurgulanması gerektiği, önemli olanlar üzerinde odaklanılması, konuşulan konular arasında bağ olması, düşüncelerin ana noktasının belirginleştirilmesi vb. gerekmektedir. Yeterlilik standardında, düşünceler kapsamlı bir şekilde aktarılmalı, konu etraflıca düşünülmeli, yeteri kadar örnek içermeli, yeteri kadar zaman ve kanıt sunulmalıdır. Derinlik/genişlik standardında; konun nedenleri en ince ayrıntısına kadar açıklanmalı, konuyla ilgili derinlemesine bilgi verilmeli, konuya farklı bakış açılarıyla bakılmalıdır. Kesinlik standardında ise; konu hatasız bir şekilde aktarılmalı, düşüncelerde kesinlik olmalı, konu yeterince ayrıntılı olmalı, olayların sebepleri açıklanmalıdır.

Günümüzde tüm devletlerin üzerinde durduğu önemli bir kavramda demokrasidir. Demokrasi, bireye değer veren ve insan kişiliğinin bütünlüğünü önemli sayan, birlikte davranan insan zekâ ve anlayışına intiyaç duyan ve karşılıklı saygı, işbirliği, hoşgörü ve doğruluk gibi nitelikleri yansıtan, toplumsal ilişkilere yer veren bir yaşam yoludur (Öncül, 2000: 290). Demokrasi, insana saygı ve eşit muamele anlayışı 
üzerinde esas anlamını bulmaktadır (Çamkerten, 2001: 17). Demokrasi kavramı eğitim alanında önemli bir yere sahiptir. Baran (2010) tarafından demokrasi eğitiminin "insan haklarına saygı, eşitlik, katılım, hoşgörü, işbirliği, güven gibi demokrasinin en temel değerlerini, bireylerin davranışlarına dönüştürmek için yürütülen tüm faaliyetleri kapsadığı" belirtilmiştir. Demokrasi kavramı bireylerin tutumlarını da etkilemektedir. Demokratik tutum; bireylerin fırsat ve imkan eşitliği, özgürlük ve adalet gibi temel kavram ve değerleri yasalarla belirlenen sınırlar çerçevesinde bir yaşam tarzı olarak hayata geçirdiği davranışlar bütünüdür (Tekin, Yıldız, Lök \& Taşğın, 2009). Demokratik bireyler; olaylara farklı açılardan bakabilen, ön yargılı olmayan, hoşgörülü, farklılıklara saygılı, düşüncelerini ifade edebilen bireylerdir (Cavkaytar, 2013; Demir, 2010). Eleştirel düşünme becerisine sahip bir bireyde olaylara farklı açıdan bakar, ön yargısızdır, hoşgörülüdür, demokratik değerlere sahiptir (Aybek, 2010; Facione \& Facione, 1996). Bu bakımdan, eleştirel düşünme ile demokrasi arasında bir ilişkiden söz edilebilir.

Türkiye'de alanyazın incelendiğinde, sınıf öğretmeni adaylarının eleştirel düşünme standartları ile demokratik tutumlarını bazı değişkenler açısından inceleyen herhangi bir çalışmaya rastlanılmamıştır. Bu durum araştırmacılar tarafından bir eksiklik olarak değerlendirilmiş ve bu çalışmanın yapılmasına karar verilmiştir. Yapılan bu araştırmanın alanyazına katkı sağlayacağı umulmaktadır.

Bu çalışmanın amacı, sınıf öğretmeni adaylarının eleştirel düşünme standartları ile demokrasiye yönelik tutumlarını bazı değişkenler açısından incelemektir. Araştırma kapsamında aşağıdaki sorulara yanıt aranmıştır:

1. Öğretmen adaylarının eleştirel düşünme standartları ile demokrasiye yönelik tutum düzeyleri nedir?

2. Öğretmen adaylarının eleştirel düşünme standartları ile demokrasiye yönelik tutumları arasında cinsiyet değişkeni açısından anlamlı farklılık var mıdır?

3. Öğretmen adaylarının eleştirel düşünme standartları ile demokrasiye yönelik tutumları arasında sınıf değişkeni açısından anlamlı farklııı var mıdır?

4. Öğretmen adaylarının eleştirel düşünme standartları ile demokrasiye yönelik tutumları arasında mezun olunan lise türü değişkeni açısından anlamlı farklılık var mıdır?

5. Öğretmen adaylarının eleştirel düşünme standartları ile demokrasiye yönelik tutumları arasında üniversiteye giriş puan türü değişkeni açısından anlamlı farklılık var mıdır?

\section{Yöntem}

\section{Araştırma Modeli}

Araştırmada, tarama modellerinden biri olan betimsel tarama modeli kullanılmıştır. Betimsel tarama, geniş gruplar üzerinde yürütülen, gruptaki bireylerin bir olgu ve olayla ilgili görüşlerinin, tutumlarının alındığı, olgu ve olayların betimlenmeye çalışıldığı araştırmalardır (Karakaya, 2012: 59). Bu araştırma yöntemi nesnelerin, toplumların, kurumların yapısını ve olayların işleyişini tanımlamak amacıyla kullanılır 
(Cohen, Manion \& Morrison, 2007). Bu araştırmada da, sınıf öğretmeni adaylarının eleştirel düşünme standartları ile demokrasiye yönelik tutumları bazı değişkenler açısından var olduğu şekliyle incelendiğinden betimsel tarama yöntemi kullanılmıştır.

\section{Evren ve Örneklem}

Araştırmanın evrenini, 2016-2017 eğitim-öğretim yılının güz döneminde Çukurova Üniversitesi'nde Sınıf Öğretmenliği ABD'de öğrenim gören öğretmen adayları oluşturmaktadır. Araştırmaya 1, 2, 3 ve 4. sınıflarda öğrenim gören 326 sınıf öğretmeni adayı katılmıştır. Evrenin çoğuna ulaşıldığı için örneklem seçimine gidilmemiştir. Öğretmen adaylarının özellikleri Tablo 1'de sunulmuştur.

Tablo 1. Öğretmen Adaylarının Özellikleri

\begin{tabular}{|c|c|c|c|c|c|}
\hline Cinsiyet & $f$ & $\%$ & Lise Türü & $f$ & $\%$ \\
\hline Kadın & 243 & 75 & Anadolu Lisesi & 178 & 55 \\
\hline Erkek & 83 & 25 & Genel Lise & 113 & 35 \\
\hline Sınıf & & & Meslek Lisesi & 35 & 10 \\
\hline 1. sinıf & 71 & 22 & \multicolumn{3}{|c|}{ Üniversiteye Giriş Puan Türü } \\
\hline 2. sinıf & 86 & 26 & Sözel & 11 & 3 \\
\hline 3. sinıf & 99 & 30 & Sayısal & 13 & 4 \\
\hline 4. sinıf & 70 & 22 & Eşit Ağırlık & 302 & 93 \\
\hline Total & 326 & 100 & Total & 326 & 100 \\
\hline
\end{tabular}

Tablo 1 incelendiğinde, kadın öğretmen adaylarının (\%75) erkek öğretmen adaylarından fazla olduğu, çoğunluğunun 3. sınıfta öğrenim gördükleri (\%30), Anadolu lisesinden mezun olduğu (\%55) ve üniversiteye giriş puan türünün eşit ağırlık olduğu (\%93) görülmektedir.

\section{Verilerin Toplanması}

Araştırmada üç tür veri toplama aracı kullanılmıştır. Bunlar:

Kişisel Bilgiler Formu: Öğretmen adaylarının kişisel bilgilerini öğrenebilmek araştırmacılar tarafından bir form geliştirilmiştir. Formda öğretmen adaylarının cinsiyetlerini, üniversiteye giriş puan türlerini, öğrenim gördükleri sınıf düzeylerini ve mezun oldukları lise türünü öğrenmek için sorular bulunmaktadır.

Eleştirel Düşünme Standartları Ölçeği: Araştırmada Aybek, Aslan, Dinçer ve Coşkun-Arısoy (2015) tarafından geliştirilen Eleştirel Düşünme Standartları Ölçeği (EDSÖ) kullanılmıştır. Ölçek geliştirilirken öncelikle açımlayıcı faktör analizi yapıımıştır. Yapılan açımlayıcı faktör analizi sonucunda ölçeğin üç faktörden ve 42 maddeden oluştuğu tespit edilmiştir. Derinlik-genişlik- yeterlilik alt boyutu 18 maddeden, kesinlikdoğruluk alt boyutu 12 maddeden ve önem-alaka-açıklık alt boyutu 12 madden oluşmaktadır. Ölçeğe ait maddelerin faktör yükleri .35 ile .78 arasında değişmektedir. Madde korelasyonları ise .07 ile .71 arasında değişmektedir. Üç alt ölçek toplam varyansın \%35.96'sını açıklamaktadır. Ölçeğin Cronbach Alpha katsayısı da incelenmiştir. Derinlik-genişlik- yeterlilik alt boyutunun Cronbach Alpha katsayısı .89, kesinlik-doğruluk alt boyutunun Cronbach Alpha katsayısı .78, önem-alaka-açıklık alt boyutunun Cronbach Alpha katsayısı .63 ve toplam Cronbach Alpha katsayısı .75 bulunmuştur (Aybek, Aslan, Dinçer \& Coşkun-Arısoy, 2015). Ölçekten alınabilecek en 
düşük puan 42 iken en yüksek puan 210'dur. Ölçekte 12 olumsuz ifade bulunmaktadır ve bu ifadeler ters çevrilip hesaplanmaktadır. Ölçek 5 'li likert şeklinde düzenlenmiştir. Ölçeğin doğrulayıcı faktör analizi de yapılmış ve ölçeğin üç alt boyuttan oluştuğu doğrulanmıştır.

Demokrasiye Yönelik Tutum Ölçeği: Çalışmada sınıf öğretmeni adaylarının demokrasiye yönelik tutumlarını ölçmek amacıyla Oral (2008) tarafından geliştirilen Demokrasiye Yönelik Tutum Ölçeği (DYTÖ) kullanılmıştır. DYTÖ 5'li likert tipi bir ölçek olup 7'si olumsuz toplam 27 maddeden oluşmaktadır. Ölçek, geliştirilirken açımlayıcı faktör analizi uygulanmıştır. Yapılan analiz sonucunda ölçeğin dört faktör altında toplandığı tespit edilmiştir. Ölçeğin, Cronbach Alpha iç tutarlılık katsayısının 0.90 olduğu rapor edilmiştir. Demokrasiye Yönelik Tutum Ölçeği'nin faktör isimleri, örnek maddeler ve Cronbach Alpha katsayıları şöyledir; Demokrasiye Eğilim ("Demokrasi eğitiminin ağırlıklı olduğu bir programdan mezun olmak isterim") 0.84 , Demokrasiye Bağılık ("Demokrasinin olmadığı bir yaşam düşünemiyorum") 0.81 , Demokrasi Niteliklerini benimseme ("Demokrasi hak, özgürlük ve adaleti sağlayan bir yönetim biçimidir") 0.84 ve Demokrasiye Olumsuz Bakış ("Demokrasi elit tabakanın yönetimidir") 0.75 . Dört faktörün açıkladığı varyans oranı ise $\% 63.4$ olarak tespit edilmiştir (Oral, 2008). Ölçekten alınabilecek en yüksek puan 135 iken en düşük puan 27 'dir.

Gerekli izin alındıktan sonra her iki ölçekte bu araştırmada kullanılmıştır. Eleştirel düşünme standartları ölçeğinin Cronbach Alpha katsayısı .91 bulunurken, demokrasiye yönelik tutuma ait ölçeğin Cronbach Alpha katsayısı .89 bulunmuştur. Bu sonuca dayalı olarak her iki ölçeğinde oldukça güvenilir olduğu söylenebilir (Seçer, 2015).

\section{Verilerin Analizi}

Araştırmanın verileri, istatistik paket programı kullanılarak analiz edilmiştir. Önce, verilerin parametrik testlerin genel koşullarını sağlayıp sağlamadığı kontrol edilmiştir. Verilerin normal dağılım gösterip göstermediğine Kolmogorov Smirnov testi ile bakılmıştır. Kolmogorov Smirnov testinde eleştirel düşünme standartları (KSZ=.049, $p>, 05)$ ve demokrasiye yönelik tutum (KSZ=.039, p>,05) ölçeklerinin normal dağılım gösterdiği tespit edilmiştir. Verilerin analizinde betimsel istatistik ve çok değişkenli varyans analizi (MANOVA) kullanılmıştır. MANOVA yapabilmek için bazı koşulların sağlanması gerekmektedir. Bu koşullardan ilki çok değişkenli normallik varsayımının karşılanıp karşılanmadığının incelenmesidir (Tabachnick \& Fidel, 2007). Araştırmada Mahalanobis uzaklık değerleri yardımıyla çok değişkenli normallik incelenmiştir. Yapılan incelemeler sonucunda verilerin çok değişkenli normalliğinin sağlandığı görülmüştür (Pallant, 2005). Araştırmada elde edilen verilerin analizinde levene testi yapılarak varyansların homojenliği de test edilmiştir (Can, 2013). Analiz sonucunda verilerin homojenliği sağlandığı tespit edilmiştir. MANOVA'nın uygulanma varsayımlardan bir diğeri de, bağımlı değişkenler arasında çoklu doğrusal bağlantının bulunmamasıdır (Field, 2009). Akbulut'a (2011) göre, bağımlı değişkenler arasındaki ilişkinin çok yüksek olması (.80 ya da .90 'nın üzerindeki korelasyon katsayıları) 
MANOVA'da sorun yaşanmasına neden olmaktadır. Yapılan analizlerde, orta düzeyde bir ilişkinin olduğu tespit edilmiştir. MANOVA'nın uygulanabilmesi için karşılanması gereken bir diğer varsayım varyans-kovaryans matrislerinin homojenliğidir. Bu şartın sağlanıp sağlanmadığı "Box's M" testi ile tespit edilmektedir. Box's M testinin istatistiksel olarak anlamlı olmaması varyans-kovaryans matrislerinin homojenliği varsayımının karşılandığını, anlamlı olması ise bu varsayımın ihlal edildiğini göstermektedir. Seçer (2015) bu test için anlamlılık ölçütünün 05 olarak alınması önermektedir. Bu araştırmada Box's M testi için anlamlılık ölçütü .05 olarak alınmıştır. Ölçeklerde yer alan maddelerin düzeyini belirlemek için aşağıda belirtilen puan aralıkları dikkate alınmıştır: Kesinlikle katılmıyorum $1.00-1.80$, Katılmıyorum 1.81 2.60, Kısmen katılıyorum $2.61-3.40$, Katılıyorum $3.41-4.20$, Kesinlikle katılıyorum $4.21-5.00$.

\section{Bulgular}

$\mathrm{Bu}$ bölümde, öğretmen adaylarının; eleştirel düşünme standartları ile demokrasiye yönelik tutum ölçeklerine katılım düzeylerinin ne olduğuna, eleştirel düşünme standartları ile demokrasiye yönelik tutumlarına ait görüşlerinde cinsiyetlerine, mezun oldukları lise türlerine, öğrenim gördükleri sınıf düzeylerine ve üniversiteye giriş puan türlerine göre anlamlı bir farklılığın olup olmadığına ilişkin bulgular yer almaktadır.

Öğretmen adaylarının eleştirel düşünme standartları ile demokrasiye yönelik tutum ölçeklerine katılım düzeyleri Tablo 2'de verilmiştir.

Tablo 2. Öğretmen adaylarının eleştirel düşünme standartları ile demokrasiye yönelik tutum ölçeklerine katılım düzeyleri

\begin{tabular}{lllllll}
\hline Değişkenler & N & $\bar{X}$ & ss & Max & Min & Düzey \\
\hline Eleştirel Düşünme Standartları & 326 & 3,95 &, 39 & 4,81 & 2,98 & Katılıyorum \\
\hline Demokrasiye Yönelik Tutum & 326 & 3,91 &, 45 & 4,85 & 2,74 & Katılıyorum \\
\hline
\end{tabular}

Tablo 2 incelendiğinde, sınıf öğretmeni adaylarının eleştirel düşünme standartları ölçeğine $(\bar{X}=3,95)$ ve demokrasiye yönelik tutum ölçeğine $(\bar{X}=3,91)$ "katılıyorum" düzeyinde görüş belirttikleri görülmektedir.

Öğretmen adaylarının eleştirel düşünme standartları ve demokrasiye yönelik tutumları ile cinsiyetlerine ilişkin tek faktörlü MANOVA sonuçları Tablo 3'te verilmiştir.

Tablo 3. Öğretmen adaylarının eleştirel düşünme standartları ve demokrasiye yönelik tutumları ile cinsiyetlerine ilişkin tek faktörlü MANOVA sonuçları

\begin{tabular}{l|l|l|l|l|l|l|l|l}
\hline Bağımlı Değişkenler & Cinsiyet & $\mathbf{n}$ & $\overline{\mathrm{X}}$ & $\mathbf{s s}$ & $\mathbf{s d}$ & $\mathbf{F}$ & $\mathbf{p}$ & $\boldsymbol{\eta}^{\mathbf{2}}$ \\
\hline \multirow{2}{*}{ Eleştirel Düşünme Standartları } & Kadın & 243 & 3,96 &, 39 & \multirow{2}{*}{$1-324$} & \multirow{2}{*}{, 046} & \multirow{2}{*}{, 14} & \multirow{2}{*}{, 00} \\
\cline { 2 - 10 } & Erkek & 83 & 3,97 &, 40 & & & \\
\hline \multirow{2}{*}{ Demokrasiye Yönelik Tutum } & Kadın & 243 & 3,93 &, 43 & \multirow{2}{*}{$1-324$} & \multirow{2}{*}{2,130} & \multirow{2}{*}{, 83} & \multirow{2}{*}{, 00} \\
\cline { 2 - 8 } & Erkek & 83 & 3,85 &, 51 & & & & \\
\hline
\end{tabular}

Öğretmen adaylarının eleştirel düşünme standartları ile demokrasiye yönelik tutumları üzerinde cinsiyetin etkisini belirlemek için tek faktörlü MANOVA yapılmıştır. MANOVA analizinin sayıltıları kontrol edildiğinde Box'ın M istatistiğine göre yayılma 
matrisinin homojenlik sayıltısı sağlanmadığı tespit edilmiştir $\left(F_{3-392734,620}=2,657 p=, 04\right)$. Akbulut (2011) çoklu varyans analizinde testin gerektirdiği şartların tutturulamaması durumunda Wilk's Lambda değerinin yerine Pillai Trace değerinin yorumlanmasını önermektedir. Pillai Trace Testi sonuçları, cinsiyetleri açısından öğretmen adaylarının eleştirel düşünme standartları ile demokrasiye yönelik tutumlarının doğrusal kombinasyonlarının anlamlı bir farklılık göstermediğini ortaya koymuştur (Pillai Trace $\left.(\lambda)=.012, F_{(1-324)}=2,008, p=.13\right)$.

Öğretmen adaylarının eleştirel düşünme standartları ile demokrasiye yönelik tutumları için yapılan tek faktörlü ANOVA sonuçları Tablo 3'te verilmiştir. Tabloda, öğretmen adaylarının eleştirel düşünme standartları $\left(F_{1-324}=, 046, p>.05\right)$ ve demokrasiye yönelik tutumları $\left(F_{1-324}=2,130, p>.05\right)$ ile cinsiyetleri arasında anlamlı farklılık bulunmamıştır. Ayrıca tablodan cinsiyet ile eleştirel düşünme standartları ve demokrasiye yönelik tutumlarının etkileşiminin düşük düzeyde etkili olduğu söylenebilir (Green \& Salkind, 2013).

Öğretmen adaylarının eleştirel düşünme standartları ve demokrasiye yönelik tutumları ile mezun oldukları lise türüne ilişkin tek faktörlü MANOVA sonuçları Tablo 4 'te verilmiştir.

Tablo 4. Öğretmen adaylarının eleştirel düşünme standartları ve demokrasiye yönelik tutumları ile mezun oldukları lise türüne ilişkin tek faktörlü MANOVA sonuçları

\begin{tabular}{|c|c|c|c|c|c|c|c|c|}
\hline $\begin{array}{l}\text { Bağımlı } \\
\text { Değişkenler }\end{array}$ & $\begin{array}{l}\text { Mezun Olunan } \\
\text { Lise Türü }\end{array}$ & $\mathbf{n}$ & $\overline{\mathrm{X}}$ & ss & sd & $\mathbf{F}$ & $\mathbf{p}$ & $\eta^{2}$ \\
\hline \multirow{3}{*}{$\begin{array}{l}\text { Eleştirel } \\
\text { Düşünme } \\
\text { Standartları }\end{array}$} & Anadolu Lisesi & 178 & 3,93 &, 40 & \multirow{3}{*}{$2-323$} & \multirow{3}{*}{2,668} & \multirow{3}{*}{, $00 *$} & \multirow{3}{*}{,03 } \\
\hline & Genel Lise & 113 & 4,02 & ,38 & & & & \\
\hline & Meslek Lisesi & 35 & 3,89 & ,36 & & & & \\
\hline \multirow{3}{*}{$\begin{array}{l}\text { Demokrasiye } \\
\text { Yönelik } \\
\text { Tutum }\end{array}$} & Anadolu Lisesi & 178 & 3,93 &, 45 & \multirow{3}{*}{$2-323$} & \multirow{3}{*}{5,118} & \multirow{3}{*}{,03* } & \multirow{3}{*}{,01 } \\
\hline & Genel Lise & 113 & 3,96 & ,44 & & & & \\
\hline & Meslek Lisesi & 35 & 3,69 & ,45 & & & & \\
\hline
\end{tabular}

${ }^{*} \mathrm{p}<, 05$

Öğretmen adaylarının eleştirel düşünme standartları ile demokrasiye yönelik tutumları üzerinde mezun olunan lise türünün etkisini belirlemek için tek faktörlü MANOVA yapılmıştır. MANOVA analizinin sayıltıları kontrol edildiğinde Box'ın M istatistiğine göre yayılma matrisinin homojenlik sayıltısı sağlandığı tespit edilmiştir $\left(F_{6}\right.$ $76705,364=1,969 p=, 06$ ). Wilks Lambda Testi sonuçları, mezun oldukları lise türü açısından öğretmen adaylarının eleştirel düşünme standartları ile demokrasiye yönelik tutumunun doğrusal kombinasyonlarının anlamlı bir farklılık gösterdiğini ortaya koymuştur (Wilk's $\left.\Lambda=.952, F_{(2-323)}=4,026, p=.00\right)$.

Öğretmen adaylarının eleştirel düşünme standartları ile demokrasiye yönelik tutumları için yapılan tek faktörlü ANOVA sonuçları Tablo 4'te verilmiştir. Tabloda, öğretmen adaylarının eleştirel düşünme standartları $\left(F_{2-323}=2,668, p<.05\right)$ ve demokrasiye yönelik tutumları $\left(F_{2-323}=5,118, p<.05\right)$ ile mezun olunan lise türü arasında anlamlı farklılık bulunmuştur. Ayrıca tablodan mezun olunan lise türü ile eleştirel düşünme standartları ve demokrasiye yönelik tutumlarının etkileşiminin düşük düzeyde etkili olduğu söylenebilir. 
Öğretmen adaylarının eleştirel düşünme standartları ve demokrasiye yönelik tutumları ile öğrenim gördükleri sınıf düzeylerine ilişkin tek faktörlü MANOVA sonuçları Tablo 5'te verilmiştir.

Tablo 5. Öğretmen adaylarının eleştirel düşünme standartları ve demokrasiye yönelik tutumları ile öğrenim gördükleri sınıf düzeylerine ilişkin tek faktörlü MANOVA sonuçları

\begin{tabular}{|c|c|c|c|c|c|c|c|c|}
\hline $\begin{array}{l}\text { Bağımlı } \\
\text { Değişkenler }\end{array}$ & $\begin{array}{l}\text { Sınıf } \\
\text { Düzeyi }\end{array}$ & $\mathbf{n}$ & $\overline{\mathrm{X}}$ & ss & sd & $\mathbf{F}$ & $\mathbf{p}$ & $\eta^{2}$ \\
\hline \multirow{4}{*}{$\begin{array}{l}\text { Eleştirel Düşünme } \\
\text { Standartları }\end{array}$} & 1. sınıf & 71 & 3,81 & ,41 & \multirow{4}{*}{$\begin{array}{l}3- \\
322\end{array}$} & \multirow{4}{*}{9,786} & \multirow{4}{*}{, $00^{*}$} & \multirow{4}{*}{, 03} \\
\hline & 2. sınıf & 86 & 3,87 & ,39 & & & & \\
\hline & 3. sınıf & 99 & 4,03 & ,30 & & & & \\
\hline & 4. sınIf & 70 & 4,10 & ,42 & & & & \\
\hline \multirow{4}{*}{$\begin{array}{l}\text { Demokrasiye } \\
\text { Yönelik Tutum }\end{array}$} & 1. sınıf & 71 & 3,89 & ,45 & \multirow{4}{*}{$\begin{array}{l}3- \\
322\end{array}$} & \multirow{4}{*}{4,310} & \multirow{4}{*}{, $00 *$} & \multirow{4}{*}{,08 } \\
\hline & 2. sınıf & 86 & 3,78 & ,41 & & & & \\
\hline & 3. sınıf & 99 & 3,97 & ,44 & & & & \\
\hline & 4. sınıf & 70 & 4,01 & ,47 & & & & \\
\hline
\end{tabular}

$\mathrm{p}<, 05$

Öğretmen adaylarının eleştirel düşünme standartları ile demokrasiye yönelik tutumları üzerinde öğrenim gördükleri sınıf düzeyinin etkisini belirlemek için tek faktörlü MANOVA yapılmıştır. MANOVA analizinin sayıltıları kontrol edildiğinde Box'ın M istatistiğine göre yayılma matrisinin homojenlik sayıltısı sağlandığı tespit edilmiştir ( $F_{9}$ $899056,844=1,660$ p=,09). Wilks Lambda Testi sonuçları, öğrenim gördükleri sınıf düzeyi açısından öğretmen adaylarının eleştirel düşünme standartları ile demokrasiye yönelik tutumunun doğrusal kombinasyonlarının anlamlı bir farklılık gösterdiğini ortaya koymuştur (Wilk's $\Lambda=.897, F_{(3-322)}=5,999, p=.00$ ).

Öğretmen adaylarının eleştirel düşünme standartları ile demokrasiye yönelik tutumları için yapılan tek faktörlü ANOVA sonuçları Tablo 5 'te verilmiştir. Tabloda, öğretmen adaylarının eleştirel düşünme standartları $\left(F_{3-322}=9,786, p<.05\right)$ ve demokrasiye yönelik tutumları $\left(F_{3-322}=4,310, p<.05\right)$ ile öğrenim gördükleri sınıf düzeyi arasında anlamlı farklılık bulunmuştur. Ayrıca tablodan öğrenim gördükleri sınıf düzeyi ile eleştirel düşünme standartlarının etkileşiminin düşük düzeyde, demokrasiye yönelik tutumlarının etkileşiminin orta düzeyde etkili olduğu söylenebilir.

Öğretmen adaylarının eleştirel düşünme standartları ve demokrasiye yönelik tutumları ile üniversiteye giriş puan türüne ilişkin tek faktörlü MANOVA sonuçları Tablo 6 'da verilmiştir.

Tablo 6. Öğretmen adaylarının eleştirel düşünme standartları ve demokrasiye yönelik tutumları ile üniversiteye giriş puan türüne ilişkin tek faktörlü MANOVA sonuçları 


\begin{tabular}{|c|c|c|c|c|c|c|c|c|}
\hline $\begin{array}{l}\text { Bağımlı } \\
\text { Değişkenler }\end{array}$ & $\begin{array}{l}\text { Üniversiteye } \\
\text { Giriş Puan }\end{array}$ & $\mathbf{n}$ & $\overline{\mathrm{X}}$ & ss & sd & $F$ & $\mathbf{p}$ & $\eta^{2}$ \\
\hline \multirow{3}{*}{$\begin{array}{l}\text { Eleştirel Düşünme } \\
\text { Standartları }\end{array}$} & Sözel & 11 & 4,18 & 49 & \multirow{3}{*}{$2-323$} & \multirow{3}{*}{2,103} & \multirow{3}{*}{,124 } & \multirow{3}{*}{,00 } \\
\hline & Sayısal & 13 & 3,88 & ,36 & & & & \\
\hline & Eşit Ağırlık & 302 & 3,95 & ,39 & & & & \\
\hline \multirow{3}{*}{$\begin{array}{l}\text { Demokrasiye } \\
\text { Yönelik Tutum }\end{array}$} & Sözel & 11 & 3,99 & ,60 & \multirow{3}{*}{$2-323$} & \multirow{3}{*}{,659 } & \multirow{3}{*}{,518 } & \multirow{3}{*}{,01 } \\
\hline & Sayısal & 13 & 3,79 & ,55 & & & & \\
\hline & Eşit Ağırlık & 302 & 3,91 & ,44 & & & & \\
\hline
\end{tabular}

Öğretmen adaylarının eleştirel düşünme standartları ile demokrasiye yönelik tutumları üzerinde üniversiteye giriş puan türünün etkisini belirlemek için tek faktörlü MANOVA yapılmıştır. MANOVA analizinin sayıltıları kontrol edildiğinde Box'ın M istatistiğine göre yayılma matrisinin homojenlik sayıltısı sağlandığı tespit edilmiştir ( $F_{6}$ ${ }_{6375,133}=1,953 p=, 06$ ). Wilks Lambda Testi sonuçları, üniversiteye giriş puan türü açısından öğretmen adaylarının eleştirel düşünme standartları ile demokrasiye yönelik tutumunun doğrusal kombinasyonlarının anlamlı bir farklılık göstermediğini ortaya koymuştur (Wilk's $\Lambda=.984, F_{(2-323)}=1,276, p=.27$ ).

Öğretmen adaylarının eleştirel düşünme standartları ile demokrasiye yönelik tutumları için yapılan tek faktörlü ANOVA sonuçları Tablo 6'da verilmiştir. Tabloda, öğretmen adaylarının eleştirel düşünme standartları $\left(F_{2-323}=2,103, p>.05\right)$ ve demokrasiye yönelik tutumları $\left(F_{2-323}=, 659, p>.05\right)$ ile üniversiteye giriş puan türü arasında anlamlı farklılık bulunmamıştır. Ayrıca tablodan üniversiteye giriş puan türü ile eleştirel düşünme standartlarının ve demokrasiye yönelik tutumlarının etkileşiminin düşük düzeyde etkili olduğu söylenebilir.

\section{Sonuç, Tartışma ve Öneriler}

Araştırma sonucunda öğretmen adaylarının; eleştirel düşünme standartları ile demokrasiye yönelik tutum ölçeklerine "katılıyorum" düzeyinde görüş belirttikleri görülmüştür. Bu sonuca dayalı olarak öğretmen adaylarının eleştirel düşünme standartlarının yüksek olduğu ve demokrasiye yönelik tutumlarının olumlu yönde ve yüksek düzeyde olduğu söylenebilir. Araştırmacılar tarafından öğretmen adaylarının eleştirel düşünme standartlarının ve demokrasiye yönelik tutumlarının yüksek düzeyde olması olumlu olarak değerlendirilmektedir. Öğretmen adaylarının eleştirel düşünme standartlarının yüksek olması, öğrencilere bu standartları kazandırmada kolaylık sağlayacaktır. Aynı şekilde öğretmen adaylarının demokrasiye yönelik tutumlarının yüksek düzeyde olması öğretme-öğrenme ortamında demokratik davranacaklarını ve öğrencilere demokrasi değerini kazandıracaklarını düşündürmektedir. Alanyazın incelendiğinde eleştirel düşünme eğilimi ile ilgili yapılan araştırmalarda benzer ve farklı sonuçlara rastlanılmıştır. Evin-Gencel ve Güzel-Candan (2014), Kuvaç ve Koç (2014) ile Kartal (2012) tarafından yapılan araştırmalarda öğretmen adaylarının eleştirel düşünme eğilimleri yüksek ve orta düzeyde çıkarken; Alkın-Şahin, Tunca, Ulubey (2014) ile Can ve Kaymakçı (2015) tarafından yapılan araştırmalarda öğretmen adaylarının eleştirel düşünme eğilimleri düşük düzeyde çıkmışır. Özdaş, Ekinci ve Bindak (2014) tarafından yapılan araştırmada da, öğretmenlerin demokrasiye yönelik tutumlarının yüksek çıktığı saptanmıştır. Uluçınar (2012), Turnsek ve Pekkarinen 
(2009) ile İnan (2013) tarafından yapılan araştırmalarda öğretmen ve öğretmen adaylarının demokratik tutumlarının yüksek düzeyde olduğu sonucu elde edilmiştir. Bu sonuçlarda, araştırmanın bu sonucunu destekler niteliktedir.

Araştırmada öğretmen adaylarının eleştirel düşünme standartları ile demokrasiye yönelik tutumları cinsiyet açısından anlamlı bir farklılık göstermemiştir. Öğretmen adaylarının eleştirel düşünme standartları ile demokrasiye yönelik tutumlarının cinsiyet açısından anlamlı bir farklıı̆ı̆ ortaya çıkmaması, cinsiyetin eleştirel düşünme standartları ve demokrasiye yönelik tutumları üzerinde etkisi olmadığı şeklinde yorumlanabilir. Alanyazın incelendiğinde bu sonucu destekleyen ve desteklemeyen araştırmaların olduğu görülmüştür. Ekinci ve Aybek (2010), Coşkun (2013) ile Kawashima ve Shiomi (2007) tarafından yapılan araştırmalarda eleştirel düşünme eğilimleri üzerinde cinsiyet değişkeni açısından anlamlı farklılık bulunmazken; Aybek ve Aslan (2015), Rudd, Baker ve Hoover (2000), Beşoluk ve Önder (2010), Çetinkaya'nın (2011) araştırmalarında da cinsiyet, eleştirel düşünmeye ilişkin görüşlerde anlamlı farklılık yaratan bir değişkendir. Özdaş, Ekinci ve Bindak (2014), tarafından yapılan araştırmada, öğretmenlerin demokrasiye yönelik tutumlarının cinsiyet açısından anlamlı farklılık yarattığı görülmüştür. Aynı şekilde Yaşar-Ekici (2014) ile Genç ve Kalafat (2007) tarafından yapılan araştırmada öğretmen adaylarının demokratik tutumları ile cinsiyetleri açısından anlamlı farklııı elde edilmiştir. Buna karşın Peker (2012) ile Genç ve Kalafat (2008) tarafından yapılan araştırmalarda öğretmen ve öğretmen adaylarının cinsiyetleri ile demokratik tutumları arasında anlamlı farklılık bulunmamıştır. Öğretmen adaylarının eleştirel düşünme standartları ile demokrasiye yönelik tutumlarının üniversiteye giriş puan türleri açısından anlamlı bir farklıık göstermediği görülmüştür. Öğretmen adaylarının eleştirel düşünme standartları ile demokrasiye yönelik tutumları ile üniversiteye giriş puan türleri arasında üniversiteye giriş puan türleri açısından benzerlik olduğu söylenebilir.

Öğretmen adaylarının eleştirel düşünme standartları ile demokrasiye yönelik tutumlarının sınıf düzeyi değişkeni açısından anlamlı farklııı olduğu sonucu elde edilmiştir. Bu da, öğretmen adaylarının eleştirel düşünme standartları ile demokrasiye yönelik tutumlarının sınıf düzeyine göre değiştiğini ortaya çıkarmaktadır. Ortalamalar incelendiğinde son sınıf öğrencilerinin eleştirel düşünme standartları ile demokratik tutumlarını daha yüksek olduğu görülmektedir. Bu da beklenen bir durumdur. Öğretmen adaylarının üniversite hayatı boyunca almış oldukları eğitim ve dersler neticesinde son sınıf öğrencilerinin eleştirel düşünme standartlarının ve demokratik tutumlarının yüksek olması beklenen bir durumdur. Bu sonuç da, beklenen bu durumu destekler niteliktedir. Ayrıca öğretim elemanlarının öğretme-öğrenme ortamında demokratik davranmaları ve eleştirel düşünme becerisi ile ilgili bilgi vermeleri de böyle bir sonucun ortaya çıkmasına neden olmuş olabilir. Alanyazın incelendiğinde bu sonucu destekleyen ve desteklemeyen araştırmalara rastlanılmıştır. Shin, Lee, Ha ve Kin (2006) tarafından yapılan araşıırmalarda sınıf düzeyi değişkenine göre öğretmen adaylarının eleştirel düşünme eğilimlerinde anlamlı farklılık bulunurken; Ekinci ve Aybek (2010) ile Piji-Küçük ve Uzun (2013) tarafından yapılan araştırmalarda da, sınıf düzeyi değişkenine göre eleştirel düşünme eğilimlerinde anlamlı farklılık 
bulunmamıştır. Genç ve Kalafat (2008) tarafından yapılan araştırmada öğretmen adaylarının demokratik tutumları ile öğrenim gördükleri sınıf düzeyi arasında anlamlı farklılık bulunmamıştır. Öğretmen adaylarının eleştirel düşünme standartları ile demokrasiye yönelik tutumlarının mezun oldukları lise türlerine göre anlamlı farklııı yarattığı sonucu elde edilmiştir. Bu sonuca dayalı olarak, öğretmen adaylarının eleştirel düşünme standartları ve demokrasiye yönelik tutumları üzerinde mezun oldukları lise türlerinin etkisi olduğu söylenebilir. Ortalamalar incelendiğinde, genel liseden mezun olan öğretmen adaylarının eleştirel düşünme standartları ile demokrasiye yönelik tutumlarının yüksek olduğu görülmüştür. Bu sonuca dayalı olarak, genel liselerde eleştirel düşünme becerisinin ve demokratik tutumun geliştirilmeye çalışıldığı söylenebilir. Aliustaoğlu ve Tuna (2015) tarafından yapılan araştırmada da, öğretmen adaylarının öğretmen adaylarının eleştirel düşünme eğilimleri ile mezun olunan lise türü değişkeni açısından anlamlı farklılık elde edilmemiştir. Bu sonuç da, yapılan bu araştırmanın sonucu ile örtüşmektedir.

Araştırma sonucuna dayalı olarak aşağıdaki öneriler geliştirilmiştir:

1. Araştırma sonucunda genel lise türünden mezun olan öğretmen adaylarının eleştirel düşünme standartları ile demokrasiye yönelik tutumları arasında anlamlı farklılık bulunmuştur. Liselerde öğrencilerin eleştirel düşünme becerilerini ve demokratik tutumlarını geliştirmeye yönelik öğretmenlerin bilgilendirilmesi faydalı olacaktır.

2. Eleştirel düşünme ve demokrasi ile ilgili deneysel ve nitel araştırmaların ve farklı veri toplama araçlarının kullanılarak araştırmalar yapılması alanyazına katkı sağlayacaktır.

3. Farklı fakültelerde öğrenim gören öğrencilerin eleştirel düşünme eğilimleri ile demokratik tutumlarını inceleyen araştırmaların yapılması alanyazına katkı sağlayabilir.

4. Öğretmen adaylarının eleştirel düşünme standartlarından ve demokratik tutumlarında çeşitli değişkenler açsından anlamlı farklılaşma olup olmadığı ile ilgili boylamsal çalışmaların yapııması alanyazına katkı sağlayacaktır.

5. Eğitim fakültelerinde öğrencilerin eleştirel düşünme standartlarını ve demokrasiye yönelik tutumlarını olumlu yönde geliştirecek öğretim programlarının hazırlanıp uygulanması yararlı olacaktır.

\section{Kaynaklar}

Akbulut, Y. (2011). Sosyal bilimlerde SPSS uygulamaları. İstanbul: İdeal.

Aliustaoğlu, F. \& Tuna, A. (2015). Öğretmen adaylarının eleştirel düşünme eğilimlerinin incelenmesi (Kastamonu Üniversitesi örneği). Uluslararası Eğitim Bilimleri Dergisi, 2(4), 131-142.

Alkın-Şahin, S., Tunca, N., \& Ulubey, Ö. (2014). Öğretmen adaylarının eğitim inançları ile eleştirel düşünme eğilimleri arasındaki ilişki. İlköğretim Online, 13(4), 14731492. http://ilkogretim-online.org.tr, Erişim Tarihi: 17.04.2015. 
Aybek, B. (2010). Örneklerle düşünme ve eleştirel düşünme. Adana: Nobel Kitapevi.

Aybek, B., \& Aslan, S. (2015). Examination of the relationship between the critical thinking dispositions of prospective teachers and their attitudes towards multicultural education trends. 3. Uluslararası Eğitim Programları ve Öğretim Kongresi (22-24/Ekim/2015), Adana: Çukurova Üniversitesi.

Aybek, B., Aslan, S., Dinçer, S. ve Coşkun-Arısoy, B. (2015). Öğretmen adaylarına yönelik eleştirel düşünme standartları ölçeği: Geçerlik ve güvenirlik çalışması. Kuram ve Uygulamada Eğitim Yönetimi, 21(1), 25-50.

Baran, S. (2010). Illköğretim 6. ve 7. sınıf öğrencilerinin demokratik tutum geliştirmesinde aile, öğretmen ve okul yönetimini algılama biçimleri. Yayımlanmamış yüksek lisans tezi. Uludağ Üniversitesi, Bursa.

Beşoluk, Ş., \& Önder, İ. (2010). Öğretmen adaylarının öğrenme yaklaşımları, öğrenme stilleri ve eleştirel düşünme eğilimlerinin incelenmesi. İlköğretim Online, 9 (2), 679-693, http://ilkogretim-online.org.tr, Erişim Tarihi: 17.04.2015.

Çamkerten, F. (2001). Okul öncesi eğitimde uygulanan program ve çocukların demokratik davranışları ile öğretmenlerin demokratik tutum ve davranışları arasındaki ilişkinin değerlendirilmesi. Yayımlanmamış yüksek lisans tezi. Ankara Üniversitesi, Ankara.

Can, A. (2013). SPSS ile nicel veri analizi. Ankara: Pegem.

Can, Ş., \& Kaymakçı, G. (2015). Öğretmen adaylarının eleştirel düşünme eğilimleri. EJournal of New World Sciences Academy, 10 (2), 66-83. http://dergipark.ulakbim.gov.tr/nwsaedu /article/view/5000075307/pdf_161. Erişim Tarihi: 17.04.2015.

Cavkaytar, S. (2013). Sınıf öğretmeni adaylarının Türkçe dersinde demokratik kültür bilincini geliştirmeye ilişkin görüşleri. Turkish Studies, 8(13), 607-631.

Cohen, L., Manion, L., \& Morrison, K. (2007). Research methods in education. New York: Routledge.

Coşkun, M.K. (2013). Din kültürü ve ahlak bilgisi öğretmen adaylarının eleştirel düşünme eğilimleri (İlahiyat-eğitim DKAB karşılaştırması). Atatürk Üniversitesi Sosyal Bilimler Enstitüsü Dergisi, 17(1), 143-162.

Çetinkaya, Z. (2011). Türkçe öğretmen adaylarının eleştirel düşünmeye ilişkin görüşlerinin belirlenmesi. Ahi Evran Üniversitesi Eğitim Fakültesi Dergisi, 12(3), 93-108.

Demir, M.K. (2010). Dört yıl arayla ilköğretim beşinci sınıf öğrencilerinin sınıf öğretmenlerinin demokratik davranışlar sergileme sıklığına ilişkin görüşleri. Türk Eğitim Bilimleri Dergisi, 8(1), 21-40.

Drennan, J. (2010). Critical thinking as an outcome of master's degree in nursing programme. Journal of Advanced Nursing, 66(2), 422-431. 
Ekinci, Ö., \& Aybek, B. (2010). Öğretmen adaylarının empatik ve eleştirel düşünme eğilimlerinin incelenmesi. Ilköğretim-Online, 9 (2), 816-827. http://ilkogretimonline.org.tr Erişim Tarihi: 17.04.2015.

Evin-Gencel, İ., \& Güzel-Candan, D. (2014). Öğretmen adaylarının eleştirel düşünme eğilimleri ve yansıtıcı düşünme düzeylerinin incelenmesi. Uluslararası Eğitim Programları ve Öğretim Çalışmaları Dergisi, 4(8), 55-68.

Facione, N.C., \& Facione, P.A. (1996). Externalizing the critical thinking in knowledge development and clinical judgment. Nursing Outlook, 44, 129-136.

Field, A. (2009). Discovering statics using SPSS. London: SAGE.

Genç, S.Z., \& Kalafat, T. (2008). Öğretmen adaylarının demokratik tutumları ile problem çözme becerilerinin çeşitli değişkenler açısından incelenmesi. Pamukkale Üniversitesi Eğitim Fakültesi Dergisi, 2(22), 10-22.

Genç, S.Z., \& Kalafat, T. (2008). Öğretmen adaylarının demokratik tutumları ile empatik becerilerinin değerlendirilmesi üzerine bir araştırma. Sosyal Bilimler Dergisi, 19, 211-222.

Green, S.B., \& Salkind, N.J. (2013). Using spss for windows and macintosh: analyzing and understanding data. New Jersey: Pearson.

Halpern, D.F. (2003). Thought knowledge: An introduction to critical thinking. London: Lawrence Erlbaum Associates.

İnan, H. (2013). Beden eğitimi öğretmenleri ve öğretmen adaylarinin demokratik tutumlarinin çeşitli değişkenlere göre incelenmesi. Yayımlanmamış yüksek lisans tezi. Abant İzzet Baysal Üniversitesi, Bolu.

Karakaya, İ. (2012). Bilimsel araştırma yöntemleri. A. Tanrı̈ğen (Edt.) Bilimsel araştırma yöntemleri içinde (s. 55-84). Ankara: Anı.

Kartal, T. (2012). İlköğretim fen bilgisi öğretmen adaylarının eleştirel düşünme eğilimlerinin incelenmesi. Ahi Evran Üniversitesi Kırşehir Eğitim Fakültesi Dergisi, 13(2), 279-297.

Kawashima, N., \& Shiomi, K. (2007). Factors of the thinking disposition of japanese high school students. Social Behavior and Perssonality an International Journal, 35(2), 187-194.

Kökdemir, D. (2003). Belirsizlik durumlarında karar verme ve problem çözme. Yayımlanmamış doktora tezi. Ankara Üniversitesi, Ankara.

Kuvaç, M., \& Koç, I. (2014). Fen bilgisi öğretmen adaylarının eleştirel düşünme eğilimleri: İstanbul Üniversitesi örneği. Turkish Journal of Education, 3(2), 4659.

MEB. (2017a). Türkçe dersi öğretim programı. Ankara: Devlet Kitapları Basımevi.

MEB. (2017b). Sosyal bilgiler dersi öğretim programı (illkokul ve ortaokul 4, 5, 6 ve 7. sınıflar). Ankara: Devlet Kitapları Basımevi. 
MEB. (2017c). Insan hakları, yurttaşlık ve demokrasi dersi öğretim programı (ilkokul 4. sınıf). Ankara: Devlet Basım Yayınevi.

Nosich, G.M. (2011). Learning to think things through: a guide to critical thinking across the curriculum. New Jersey: Prentice-Hall.

Oral, B. (2008). The evaluation of the student teachers' attitudes toward Internet and democracy. Computers \& Education, 50(1), 437-445.

Öncül, R. (2000). Eğitim ve eğitim bilimleri sözlüğü. İstanbul: Milli Eğitim Bakanlığı Yayınları.

Özdaş, F., Ekinci, A., \& Bindak, R. (2014). Öğretmenlerin demokrasiye ilişkin tutumlarının bazı değişkenler açısından incelenmesi. Inönü Üniversitesi Eğitim Fakültesi Dergisi, 15(3), 65-81.

Pallant, J. (2005). Spss survival manual: a step by step guide to data analysis using spss for windows. Australia: Australian Copyright.

Paul, R., \& Elder L. (2007). The miniature guide to critical thinking: Conceptsand tools. Foundation for Critical Thinking Press.

Peker, R. (2012). Sınıf öğretmenlerinin demokratik tutumları ile çocuk haklarına yönelik tutumlarının değerlendirilmesi (Manisa ili örneği). Yayımlanmamış yüksek lisans tezi. Mehmet Akif Üniversitesi, Hatay.

Piji-Küçük, D., \& Uzun, Y.B. (2013). Müzik öğretmeni adaylarının eleştirel düşünme eğilimleri. Ahi Evran Üniversitesi Kırşehir Eğitim Fakültesi Dergisi, 14(1), 327345.

Rudd, R., Baker, M., \& Hoover, T. (2000). Undergraduate agriculture student learning styles and critical thinking abilities: Is there a relationship. J. Agric. Education, 41(3), 2-12.

Seçer, İ. (2015). SPSS ve Lisrel ile pratik veri analizi: analiz ve raporlaştırma. Ankara: Anı.

Shin, K.R., Lee, .J.H., Ha, J.Y., \& Kim, K.H. (2006). Critical thinking dispositions in baccalaureate nursing students. Journal of Advanced Nursing, 56(2), 182-189.

Tabachnick, B.G., \& Fidell, L.S. (2007). Using multivariate statistics. Boston, Pearson Education, Inc.

Tekin, M., Yıldız, M., Lök, S., \& Taşğın, Ö. (2009). Beden eğitimi ve spor yüksekokulunda öğrenim gören öğretmen adaylarının çeşitli değişkenlere göre demokratik tutum düzeylerinin incelenmesi. Niğde Üniversitesi Beden Eğitimi ve Spor Bilimleri Dergisi, 3 (3).

Turnsek, N., \& Pekkarinen, A. (2009). Democratisation of early chilhood education in the attidudes of slovene and finnish teachers. European Early Childhood Education Research Journal , 17(1), 23-42. 
Yaşar-Ekici, F. (2014). Öğretmen adaylarının demokratik tutumları ve demografik özellikleri arasındaki ilişkinin incelenmesi. Turkish Studies, 9(11), 593-602. 